Косяк Антоніна Петрівна кандидат економічних наук, доцент, доцент кафедри фінансово-економічної безпеки, обліку i аудиту, Харківський національний університет міського господарства імені О. М. Бекетова, вул. Маршала Бажанова, 17, м. Харків, 61002, тел.: (057) 707-31-71, https://orcid.org/0000-0003-1009-4082

Краївська Інна Анатоліївна кандидат економічних наук, доцент кафедри фінансово-економічної безпеки, обліку i аудиту, Харківський національний університет міського господарства імені О. М. Бекетова, вул. Маршала Бажанова, 17, м. Харків, 61002, тел.: (057) 707-31-71, https://orcid.org /0000-0002-5701-8557

\title{
ОБЛІКОВО-АНАЛІТИЧНЕ ЗАБЕЗПЕЧЕННЯ ЩОДО ОПЛАТИ ПРАЦІ ПЕРСОНАЛУ КОМУНАЛЬНИХ НЕКОМЕРЦЙНИХ ПДПРИСМСТВ СИСТЕМИ ОХОРОНИ ЗДОРОВ'Я В УМОВАХ COVID-19 (НА ПРИКЛАДІ КНП «МІСЬКОЇ ДИТЯЧОЇ ПОЛІКЛІНІКИ № 1» ХАРКІВСЬКОЇ МІСЬКОЇ РАДИ)
}

Анотація. У статті висвітлені теоретичні питання щодо поняття «оплата праці» та «заробітна плата», як соціально-економічної категорії, яка служить основним засобом задоволення особистих потреб працівників. Розглянуто нормативно-правове законодавство в Україні та регулювання оплати праці найманих працівників комунальних некомерційних підприємств системи охорони здоров'я, обліково-аналітичне забезпечення розрахунків з персоналом по оплаті праці та утримання із заробітної плати. Обгрунтовані основні форми i системи оплати праці щодо їх використання в системі охорони здоров'я.

Досліджено та узагальнено відомості про практичну діяльність комунального некомерційного підприємства «Міська дитяча поліклініка № 1» Харківської міської ради, встановлено умови організації оплати праці, нормування, доплати, надбавки, преміювання.

Оплата праці персоналу комунального некомерційного підприємства нараховується відповідно до Колективного договору, Положення про оплата праці, Положення про преміювання в межах фонду оплати праці, виходячи із установлених: посадових окладів, визначених за відповідними тарифними розрядами Єдиної тарифної сітки, згідно штатного розпису; підвищення посадових окладів (за наявності кваліфікаційної категоріі); надбавок (за вислугу років); премій, розміри якої залежить від особистого внеску в загальні результати роботи комунального некомерційного підприємства.

Система обліку, зокрема оплата праці, перебуває в процесі реформування 
відповідно до міжнародних стандартів бухгалтерського обліку, це пов'язано 3 тим, що праця як об'єкт обліку є однією 3 найскладніших і найвагоміших економічних категорій, оскільки покликана виконувати життєво необхідні для людини відтворювальну, регулюючу, стимулюючу та соціальну функції.

Ключові слова: оплата праці, комунальне некомерційне підприємство, обліково-аналітичне забезпечення, організація оплата праці, облік праці.

Kosiak Antonina Petrovna $\mathrm{PhD}$ in Economics, docent, docent kafedry finansovo-ekonomichnoyi bezpeky, obliku i audytu O. M. Beketov National University of Urban Economy in Kharkiv, Marshala Bazhanova St., 17, Kharkiv, 61002, tel.: (057) 707-31-71, https://orcid.org/0000-0003-1009-4082

Kraivska Inna Anatoliyivna $\mathrm{PhD}$ in Economics, docent kafedry finansovoekonomichnoyi bezpeky, obliku i audytu O. M. Beketov National University of Urban Economy in Kharkiv, Marshala Bazhanova St., 17, Kharkiv, 61002, tel.: (057) 707-31-71, https://orcid.org /0000-0002-5701-8557

\section{OBLIKOVO-ANALITYCHNE ZABEZPECHENNYA SHCHODO OPLATY PRATSI PERSONALU KOMUNAL'NYKH NEKOMERTSIYNYKH PIDPRYYEMSTV SYSTEMY OKHORONY ZDOROV"YA V UMOVAKH COVID-19 (NA PRYKLADI KNP «MIS'KOYI DYTYACHOYI POLIKLINIKY № 1» KHARKIVS'KOYI MIS'KOYI RADY)}

Abstract. The article highlights the theoretical issues of the concept of "wages" and "wages" as a socio-economic category, which is the main means of meeting the personal needs of employees. The normative-legal legislation in Ukraine and regulation of remuneration of employees of communal non-profit enterprises of the health care system, as well as accounting and analytical support of settlements with the staff on remuneration and deductions from wages are considered. The basic forms and systems of remuneration for their use in the health care system are substantiated.

The information on the practical activity of the municipal non-profit enterprise "City Children's Polyclinic № 1" of the Kharkiv City Council is researched and generalized, the conditions of the organization of wages, rationing, surcharges, allowances, bonuses are established.

Remuneration of the staff of the municipal non-profit enterprise is accrued in accordance with the Collective Agreement, Regulations on Remuneration, Regulations on Bonuses within the Remuneration Fund, based on established: salaries determined by the relevant tariff categories of the Unified Tariff Grid, according to the staff list; increase of salaries (if there is a qualification category); allowances (for years of service); bonuses, the amount of which depends on the personal contribution to the overall results of the municipal non-profit enterprise. 


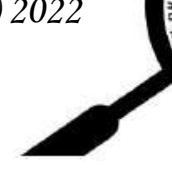

The accounting system, in particular wages, is in the process of reforming in accordance with international accounting standards, this is due to the fact that labor as an object of accounting is one of the most complex and important economic categories, as it is designed to perform vital human reproduction, regulatory, stimulating and social functions.

Keywords: wages, municipal non-profit enterprise, accounting and analytical support, organization wages, labor accounting.

Постановка проблеми у загальному вигляді та іï зв'язок з важливими науковими, чи практичними, завданнями. На сьогодні в сучасних умовах господарювання досить актуальним питанням на комунальних некомерційних підприємствах системи охорони здоров'я є обліково-аналітичне забезпечення та організація обліку оплати праці персоналу. У зв'язку з нестабільною та постійною зміною законодавчої та нормативної бази України необхідна своєчасна організація обліку розрахунків 3 оплати праці. Вірно та чітко організований облік дасть змогу приділити належну увагу нарахуванню оплати праці персоналу та порядку утримання із заробітної плати.

Аналіз останніх досліджень і публікацій. Дослідженнями проблем теоретичних i методологічних основ, а також особливостями організації бухгалтерського обліку з оплати праці персоналу комунальних некомерційних підприємств охорони здоров'я займалися відомі вітчизняні вчені, такі як: Й. П. Атамас, О. П. Атамас, О. В. Артюх, О. Ю. Акименко, Ф. Ф. Бутинець, Ю. А. Верига, В. С. Лень, Т. П. Романенко, І. І. Сахарцева та багато інших. Незважаючи на значні позитивні зміни в організації обліку в КНП ОЗ, що спостерігаються за останні роки, цьому сприяла нормативна діяльність Міністерства фінансів України, але є ряд важливих питань, що стосується насамперед теоретичних, методологічних та організаційних проблем обліку оплати праці працівників у умовах covid-19 залишаються не вирішені повною мірою. Тому, незважаючи на те, що всі Національні положення (стандарти) бухгалтерського обліку (НП(С)БО) більшою мірою сформовані на базі міжнародних стандартів бухгалтерського обліку (МСБО), але вони мають свої особливості, що обумовлені економікою України.

Мета статті - дослідження теоретичних засад поняття «оплата праці», нормативно-правової бази, порядок організації оплати праці персоналу комунальних некомерційних підприємств системи охорони здоров'я та обліку оплати праці.

Виклад основного матеріалу. Для успішного функціонування в умовах ринкової економіки комунальним некомерційним підприємствам необхідно мати такий тип економічної поведінки, що дозволяв би адаптуватися до динамічних умов зовнішнього середовища.

Питання обліково-аналітичного забезпечення та порядок організації розрахунків 3 оплати праці персоналу комунального некомерційного 
підприємства «Міська дитяча поліклініка № 1» Харківської міської ради $\epsilon$ досить актуальними та вимагають ефективного здійснення відповідно до законодавчо-нормативних актів України, а саме: Конституції України [1], Кодексу законів про працю України [2], Податкового кодексу України [3], Господарський кодекс України [4], Закону України «Про оплату праці» [5] та інших нормативних актів.

Зокрема, зазначимо, що трудові відносини в Україні між роботодавцем i працівниками регулюються багаться законодавчими та нормативними актами, але основним законодавчим актом $є$ Конституція України, на якій базується все законодавство України. Так, ст. 43 Конституції України № 254к/96-ВР від 28.06.1996 (поточна редакція від 01.01.2020) наголошує, що кожен має право на належні, безпечні та здорові умови праці, на заробітну плату, не нижчу від визначеної законом [1].

Кодекс законів про працю України № 332-VIII від 10.12.1971 (поточна редакція від 15.12.202) є основним законодавчим актом, що регулює трудові відносини всіх працівників, сприяючи зростанню продуктивності праці, поліпшенню якості роботи, підвищенню ефективності суспільного виробництва та піднесенню на цій основі матеріального і культурного рівня життя трудящих, зміцненню трудової дисципліни й поступовому перетворенню праці на благо суспільства в першу життєву потребу кожної працездатної людини.

Відповідно до ст. 94 «Заробітна плата» глави VII «Оплата праці» КЗпП заробітна плата - це винагорода, обчислена, як правило, у грошовому виразі, яку власник або уповноважений ним орган виплачує працівникові за виконану ним роботу [2].

Слід зазначити те, що розмір заробітної плати залежить від складності та умов виконуваної роботи, професійно-ділових якостей працівника, результатів його праці та господарської діяльності підприємства, установи, організації і максимальним розміром не обмежується. Питання державного та договірного регулювання оплати праці, прав працівників на оплату праці та їх захисту визначається КЗпП України, Законом України «Про оплату праці» та ін. нормативно-правовими актами.

Згідно зі ст. 95 КЗПП мінімальна заробітна плата - встановлений законом мінімальний розмір оплати праці за виконану працівником місячну (годинну) норму праці [2]. Так, мінімальна зарплата $є$ державною соціальною гарантією, обов'язковою на всій території України для підприємств, установ, організацій усіх форм власності і господарювання та фізичних осіб, які використовують працю найманих працівників, за будь-якою системою оплати праці.

Податковий кодекс України (ПКУ) № 2755-VI від 02.12.2010 (поточна редакція від 21.11.2021) регулює відносини, що виникають у сфері справляння податків і зборів, зокрема визначає вичерпний перелік податків та зборів, що справляються в Україні, та порядок їх адміністрування, платників податків і 
зборів, їх права та обов'язки, компетенцію контролюючих органів, повноваження й обов'язки їх посадових осіб під час адміністрування податків та зборів, а також відповідальність за порушення податкового законодавства.

Відповідно до ст. 14 п. 14.1.48 ПКУ заробітна плата для цілей розділу IV «Податок на доходи фізичних осіб» - основна та додаткова заробітна плата, інші заохочувальні та компенсаційні виплати, які виплачуються (надаються) платнику податку у зв’язку з відносинами трудового найму згідно із законом [3].

Варто зазначити, що згідно ст. 162 пп. 162.1 ПКУ платниками податку на доходи фізичних осіб (ПДФО) є: фізична особа - резидент, яка отримує доходи як 3 джерела їх походження в Україні, так і іноземні доходи; фізична особа - нерезидент, яка отримує доходи 3 джерела їх походження в Україні; податковий агент.

Базою оподаткування податку на ПДФО є загальний оподаткований дохід платника податку згідно ст. 164 ПКУ.

Згідно зі ст. 54 «Регулювання некомерційної господарської діяльності»

Господарського кодексу України (ГКУ) № 436-IV від 16.01.2003 (поточна редакція від 19.12.2021) на суб'єктів господарювання, які здійснюють некомерційну господарську діяльність поширюються загальні вимоги щодо регулювання господарської діяльності 3 урахуванням особливостей иï здійснення різними суб'єктами господарювання, які визначаються ГКУ [4] та ін. законодавчими актами. Отже, при визначенні умов праці працівників КНП та при укладенні трудових договорів (контрактів, угод) суб'єкт господарювання, що здійснює некомерційну господарську діяльність, зобов'язаний забезпечити належні та безпечні умови праці, їі оплату не нижчу від визначеного законом мінімального розміру, а також забезпечити ін. соціальні гарантії, передбачені законом. Адже, керуючись ГКУ КНП самостійно визначають структуру, штатну чисельність та систему оплати праці для своїх працівників.

Закон України «Про оплату праці» № 108/95-ВР від 24.03.1995 (поточна редакція - Визнання конституційними окремих положень від 15.07.2021) визначає економічні, правові та організаційні засади оплати праці працівників, які перебувають у трудових відносинах, на підставі трудового договору 3 підприємствами, установами, організаціями усіх форм власності та господарювання, а також 3 окремими громадянами та сфери державного i договірного регулювання оплати праці й спрямований на забезпечення відтворювальної та стимулюючої функцій заробітної плати.

Відповідно до розділу I ст. 1 «Заробітна плата» Закону України «Про оплату праці» заробітна плата - це винагорода, обчислена, як правило, у грошовому виразі, яку за трудовим договором роботодавець виплачує працівникові за виконану ним роботу [5].

Структура заробітної плати на підприємствах визначається ст. 2 Закону України «Про оплату праці» і включає такі складові: основну заробітну 
плату, додаткову заробітну плату, інші заохочувальні та компенсаційні виплати.

Основна заробітна плата - винагорода за виконану роботу відповідно до встановлених норм праці (норми часу, виробітку, обслуговування, посадові обов'язки) та встановлюється у вигляді тарифних ставок (окладів) і відрядних розцінок для робітників та посадових окладів для службовців.

Додаткова зарплата - винагорода за працю понад установлені норми, за трудові успіхи та винахідливість і за особливі умови праці, яка включає доплати, надбавки, гарантійні і компенсаційні виплати, передбачені чинним законодавством; премії, пов'язані з виконанням виробничих завдань і функцій.

До інших заохочувальних і компенсаційних виплат належать виплати у формі винагород за підсумками роботи за рік, премії за спецсистемами i положеннями, виплати в рамках грантів, компенсаційні та ін. грошові й матеріальні виплати, які не передбачені актами чинного законодавства або які провадяться понад встановлені зазначеними актами норми.

Найважливішим об'єктом обліку на КНП маємо вважати оплату праці та облік розрахунків із заробітної плати з персоналом.

Умови та розміри оплати праці працівників, що фінансуються з бюджету, встановлюються Кабінетом Міністрів України відповідно до ст. 8 «Сфера державного регулювання оплати праці» Закону України «Про оплату праці», так держава здійснює регулювання оплати праці працівників підприємств усіх форм власності шляхом встановлення розміру мінімальної заробітної плати та ін. державних норм і гарантій, встановлення умов і розмірів оплати праці керівників підприємств, заснованих на державній, комунальній власності, працівників підприємств, установ та організацій, що фінансуються чи дотуються з бюджету, а також шляхом оподаткування доходів працівників.

Методологічні засади формування в бухгалтерському обліку інформації про виплати (у грошовій i негрошовій формах) за роботи, виконані працівниками, та іï розкриття у фінансовій звітності визначає Національне положення (стандарт) бухгалтерського обліку 26 «Виплати працівникам» від 28.10.2000 р. № 601 (поточна редакція від 03.11.2020) [6], яке стало застосовуватися КНП «МДП № 1» ХМР з 01 січня 2018 р.

Результати проведеного дослідження показали, що вітчизняне НП(С)БО 26 «Виплати працівникам», є аналогом МСБО 19 «Виплати працівникам», який практично не змінює існуючої системи розрахунків із працівниками і має стандартизувати облік цих розрахунків та створює необхідну інформаційну базу, що є позитивним аспектом.

В умовах ринкової економіки основними і важливими завданнями організації обліку розрахунків з оплати праці є наступні:

- відображення точної, достовірної інформації щодо персоналу;

- організація повної реєстрації та своєчасної обробки первинних документів з обліку розрахунків із оплати праці; 


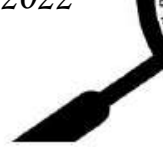

- організація безперервності інформаційних потоків між структурними підрозділами та відділом бухгалтерії КНП щодо оплати праці;

- організація своєчасного нарахування та виплати заробітної плати;

- своєчасне перерахування до державних бюджетів й фондів податків і обов'язкових платежів, внесків до державного соціального страхування, пов'язаних з нарахуваннями та виплатою заробітної плати персоналу.

Оплата праці персоналу КНП «МДП № 1» ХМР здійснюється на підставі Конституції України, КЗпП України, Господарського та Податкового кодексів України, Закону України «Про оплату праці» та інших нормативно-правових актів, Генеральної, Територіальної та Галузевої угод, Колдоговору 3 дотриманням гарантій, встановлених чинним законодавством України.

КНП відповідно до Колективного договору проводить розрахунки 3 оплати праці із персоналом охорони здоров'я та зобов'язується:

- переглядати розмір мінімальної зарплати з урахуванням Закону України «Про Державний бюджет України» на відповідний рік;

- затверджувати у штатному розписі найменування посад працівників за Національним класифікатором «Класифікатор професій» ДК: 003 - 2010;

- розміри посадових окладів (ставок), їх підвищення, доплати, надбавки встановлювати на рівні не нижчому, ніж визначені спільними наказами Міністерства праці та соціальної політики України, Міністерства охорони здоров'я України «Про впорядкування умов оплати праці працівників закладів охорони здоров'я та установ соціального захисту населення» від 05.10.2005 р. № 308/519 [7].

А також постановами Кабінету Міністрів України:

- Про оплату праці працівників на основі Сдиної тарифної сітки розрядів і коефіцієнтів 3 оплати праці працівників установ, закладів та організацій окремих галузей бюджетної сфери від 30.08.2002 p. № 1298;

- Про затвердження Порядку виплати надбавки за вислугу років медичним та фармацевтичним працівникам державних та комунальних закладів охорони здоров’я від 29.12.2009 р. № 1418;

- Про деякі заходи щодо підвищення престижності праці медичних працівників, які надають медичну допомогу хворим на туберкульоз від 16.02.2011 p. № 123;

- Деякі питання оплати праці працівників протитуберкульозних закладів від 20.03.2013 р. № 174;

- Деякі питання оплати праці медичних працівників системи екстреної медичної допомоги від 27.03.2013 р. № 199;

- Деякі питання оплати праці медичних працівників, що надають первинну медичну допомогу від 30.12.2013 р. № 977;

- Питання оплати праці працівників установ, закладів та організацій окремих галузей бюджетної сфери від 11.05.2011 р. № 524.

У Колдоговорі та Положенні про оплату праці КНП «МДП № 1» ХМР на 
основі законодавчої бази i нормативно-правових актів розроблені та здійснюються згідно наказу Міністерства праці та соціальної політики України і Міністерства охорони здоров’я України № 308/519 підвищення посадових окладів (тарифних ставок) наступному персоналу [7]:

- за керівництво структурним підрозділом, завідувачам структурних підрозділів, лікарям, керівникам 3 числа фахівців 3 базовою та неповною вищою медичною освітою (старшим сестрам медичним, фельдшерам тощо) (згідно пп. 2.2.3 та пп. 2.2.9 п. 2 р. 2);

- старшим сестрам медичним та іншим фахівцям з базовою та неповною вищою медичною освітою (згідно пп. 2.2.10 п. 2 р. 2);

- за наявності кваліфікаційної категорії: керівникам КНП та їх заступникам з числа лікарів і провізорів, керівникам з числа фахівців з базовою та неповною вищою медичною освітою та головним сестрам медичним (головним фельдшерам (згідно пп. 2.4.1 п. 2.4 р. 2));

- за оперативне втручання: лікарям-хірургам усіх найменувань до $15 \%$ посадового окладу, до 25 \% денному стаціонарі хірургічного профілю, до 40 \% у стаціонарі (згідно пп. 2.4.2 п. 2.4 р. 2);

- за диплом з відзнакою: лікарям, які отримали диплом з відзнакою після закінчення медичних навчальних закладів оклад підвищується протягом п'яти років у розмірі $5 \%$ (згідно пп. 2.4 .3 п. 2.4 р. 2);

- за керування санітарним транспортом: водіям санітарних автомобілів 20 \% місячної тарифної ставки (перелік автомобілів віднесених до санітарних, затверджується МОЗУ (згідно пп. 2.4.4. п. 2.4 р. 2));

- у зв’язку зі шкідливими і важкими умовами праці працівникам закладів та структурних підрозділів у розмірі $15 \%, 20 \%, 25 \%, 30 \%, 60 \%$ (перелік яких приведено у додатку 3 (згідно пп. 2.4.5 п. 2.4 р. 2);

- інші підвищення посадових окладів (тарифних ставок) (згідно пп. 2.4.6 п. 2.4 р. 2).

На КНП «МДП № 1» ХМР встановлені наступні доплати:

- за суміщення професій (посад), виконання обов'язків тимчасово відсутнього працівника та розширення зони обслуговування або збільшення обсягу виконуваних робіт у розмірі до 50 \% (пп. 3.1 п. 3 наказ МОЗ України);

- за ненормований робочий день для водіїв легкових та санітарних автомобілів 3 доплатою 25 \% тарифної ставки за відпрацьований час (пп. 3.4.4 п. 3 наказ МО3 України);

- працівникам, зайнятим на роботах зі шкідливими і важкими умовами праці, за результатами атестації робочих місць, в розмірі до $15 \%$ посадового окладу (перелік робіт з шкідливими і важкими умовами праці приведений у додатку 6 (пп. 3.4.5 п. 3 наказ МО3 України));

- працівникам, які використовують у роботі дезінфікуючі засоби та зайняті прибиранням санвузлів, у розмірі $10 \%$ посадового окладу (пп. 3.4 .7 п. 3 наказ МО3 України). 
На КНП «МДП № 1» ХМР встановлені надбавки:

- за вислугу років медичним і фармацевтичним працівникам надбавка у розмірі до 30 \% посадового окладу залежно від стажу роботи (Постанова КМУ від 29.12.2009 р. № 1418);

- за тривалість безперервної роботи (згідно пп. 4.1 наказу МОЗ України) у розмірі та згідно з переліком посад, наведеним у додатку № 7 до колективного договору;

- за почесні звання «заслужений» 20 \% посадового окладу, «народний» 40 \% посадового окладу (згідно пп. 4.2.1 наказу МОЗ України);

- за високі досягнення у праці, за виконання особливо важливої роботи (на строк іiі виконання), складність, напруженість у роботі у розмірі до $50 \%$ посадового окладу (пп. 4.4 п. 4 наказу МОЗ України);

- робітникам, які мають III-VI кваліфікаційні розряди, установлені інші надбавки за професійну майстерність у відсотках до тарифних ставок у розмірах: III розряд - $12 \%$, IV розряд - $16 \%$, V розряд - $20 \%$, VI розряд - $24 \%$ (згідно пп. 4.5.2 наказу МОЗ України);

- водіям легкових автомобілів установлена щомісячна надбавка за класність до тарифної ставки за фактично відпрацьований час: водіям II класу 10 \%; водіям I класу - 25 \% (згідно пп. 4.5.3 наказу МОЗ України).

При встановленні доплат та надбавок, які не мають обов'язкового характеру, визначення першочерговості їх встановлення враховуються рекомендації (пропозиції) профкому КНП. Максимальні розміри доплат та надбавок, що не носять обов'язкового характеру і передбачають можливість встановлення різних розмірів відсоткового співвідношення до посадового окладу, надаються з врахуванням рекомендацій профспілкового комітету.

Щодо виплати медичному персоналу (лікарям, середньому медичному персоналу) матеріальної допомоги на оздоровлення в розмірі посадового окладу під час надання основної щорічної відпустки установлено ч. 2 п. 3 Постанови КМУ від 11.05.2011 p. № 524.

Надання іншим працівникам КНП, які не відносяться до медичного персоналу, матеріальної допомоги, у т. ч. на оздоровлення, у сумі не більше ніж одного посадового окладу на рік (крім матеріальної допомоги на поховання), у межах фонду заробітної плати відповідно до п. 5.11 наказу МОЗ України.

Преміювання персоналу КНП здійснювати згідно 3 «Положенням про преміювання» за рахунок ФОП, затвердженого кошторисом й за рахунок надходжень від надання платних послуг у розмірі до $30 \%$ та за погодженням 3 профспілковим комітетом.

При переведені працівників на іншу нижче оплачувану роботу, оплату праці необхідно проводити згідно ст. 114 і ст. 170 КЗПП України, а за роботу в святкові та неробочі дні понад місячну норму робочого часу оплачувати у розмірі подвійної годинної або денної ставки понад оклад згідно ст. 107 КЗпП України [2]. 
Нарахування оплати праці персоналу являє собою розрахунок заробітної плати за місяць з урахуванням посадового окладу, різних доплат і надбавок, премій, вислуги років, допомоги, оплати відпусток за мінусом суми відрахувань. Нарахування заробітної плати здійснюється на підставі первинних документів з обліку фактично відпрацьованого часу, виробітку, доплатних листків, наказів та інших документів.

При погодинній оплаті праці підставою для нарахування зарплати $\epsilon$ «Табель обліку використання робочого часу» типової форми № П-5, який складають в окремих підрозділах підприємства і за підписом керівника підрозділу та особи, уповноваженої вести облік виходу на роботу персоналу подають до відділу бухгалтерії КНП. Бухгалтер, відповідальний за нарахування зарплати, перевіряе «Табель ...», як 3 точки зору правильності його оформлення, так і за змістом: склад осіб, внесених до Табеля, погодження 3 відповідними документами, тобто, дати відпустки, дати хвороби, відрядження, зарахування або звільнення працівника, а також відображається робота у святкові та неробочі дні, у нічні зміни тощо. Перевіряється також правильність підрахунку кількості відпрацьованих годин (днів) кожним працівником та кількості невиходів на роботу 3 різних причин. Нарахування зарплати за відпрацьований час може здійснюватися безпосередньо в типовій формі № П-6 «Розрахунок платіжних відомостей працівника», виходячи 3 кількості відпрацьованих днів (год.) та встановленого місячного окладу (погодинної ставки).

Основними формами оплати праці на КНП «МДП № 1» ХМР є погодинна та відрядна. Зокрема, погодинна форма оплати праці застосовується, як вимірник результатів праці, коли використовують кількість відпрацьованих годин. Відрядна форма оплати праці застосовується у разі, якщо вимірником результатів праці є виконання робіт або наданих послуг. Тобто погодинну форму оплати праці застосовують за результатами виконання складної інтелектуальної, творчої роботи, а відрядну - при простій повторюваній праці.

Системами оплати праці є: погодинно-преміальна й відрядно-преміальна, але переважає, як правило, погодинно-преміальна. Основою обліковоаналітичного забезпечення оплати праці $є$ тарифна система, яка включає тарифні сітки, тарифні ставки, схеми посадових окладів, тарифнокваліфікаційні характеристики.

Нарахування заробітної плати на КНП має свої особливості та суттєві відмінності. Так, в системі охорони здоров'я посадові оклади лікарів диференціюють залежно від посади й категорії (вища, перша, друга, без категорії); типу медичної установи (стаціонар, поліклініка), з підвищенням посадових окладів за керівництво відділенням, кабінетом, лабораторією, відділом тощо. Посадові оклади середнього медперсоналу диференціюють залежно від посади та категорії. 


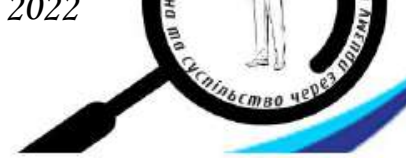

Облік заробітної плати в системі рахунків - це синтетичний облік нарахування i розподілу заробітної плати, визначення належної суми працівникам і віднесення нарахованої оплати праці на відповідні рахунки витрат за статтями і об'єктами калькулювання.

Для обліку розрахунків з персоналом за всіма видами оплати праці у Плані рахунків бухгалтерського обліку активів, капіталу, зобов'язань і господарських операцій підприємств і організацій № 291 передбачено пасивний рахунок 6-го класу 66 «Розрахунки за виплатами працівників» у розрізі субрахунків: 661 «Розрахунки за заробітною платою», 662 «Розрахунки 3 депонентами», 663 «Розрахунки за іншими виплатами» [8].

На синтетичному рахунку 66 «Розрахунки за виплатами працівників» ведеться узагальнення інформації про розрахунки з персоналом, який належить як до облікового, так і до не облікового складу підприємства з оплати праці (за всіма видами зарплати, премій, допомоги тощо), а також розрахунки за неодержану персоналом у встановлений термін суму 3 оплати праці (розрахунки з депонентами).

За кредитом субрахунку 661 «Розрахунки за заробітною платою» відображають нарахування персоналу: основної та додаткової заробітної плати, премій, інших виплат, що входять до фонду оплати праці (ФОП).

За дебетом субрахунку 661 «Розрахунки за заробітною платою» відображають: виплачену зарплату, премії, інші виплати, що входять до ФОП, депоновані суми зарплати, суми утриманих податку з доходів фізичних осіб (ПДФО) 18\%, військового збору (В3) 1,5\%, профспілкових внесків (ПВ) 1\%, суми утриманих платежів за виконавчими документами та інші утримання 3 виплат персоналу.

Субрахунок 662 «Розрахунки 3 депонентами» використовують тільки для того, щоб відображати розрахунки за не отриманою персоналом 3 каси в установлений строк сумою оплати праці. У такому разі роблять запис:

Д-т 661 або Д-т 663 та К-т 662

Субрахунок 663 «Розрахунки за іншими виплатами» ведеться облік розрахунків за виплатами, що не належать до ФОП, зокрема, допомога по частковому безробіттю, допомога по тимчасовій непрацездатності. Аналітичний облік розрахунків ведеться за кожним працівником, видами виплат та утримань.

Відображення бухгалтерських проведень із нарахування та утримання із заробітної плати персоналу КНП «МДП № 1» ХМР наведено у табл. 1. 
Бухгалтерські проведення із нарахування та утримання із заробітної плати персоналу

\begin{tabular}{|c|l|c|c|c|}
\hline \multirow{2}{*}{$3 /$} & \multicolumn{1}{|c|}{ Зміст господарської операції } & \multicolumn{2}{|c|}{$\begin{array}{c}\text { Кореспонден } \\
\text { ція рахунків }\end{array}$} & \multirow{2}{*}{$\begin{array}{c}\text { Сума, } \\
\text { прн. }\end{array}$} \\
\cline { 2 - 4 } Дебет & \multicolumn{1}{|c|}{ Кредит } & грн \\
\hline 1 & $\begin{array}{l}\text { Нарахована зарплата персоналу, що перебуває у } \\
\text { штаті КНП і фінансується за рахунок міцевого } \\
\text { бюджету }\end{array}$ & 92 & 661 & 28676,89 \\
\hline 2 & Утримано із заробітної плати ПДФО 18\% & 661 & 641 & 5161,84 \\
\hline 3 & Утримано із заробітної плати В3 1,5\% & 661 & 6421 & 430,15 \\
\hline 4 & $\begin{array}{l}\text { Утримано із заробітної плати профспілкові } \\
\text { внески 1\% }\end{array}$ & 661 & 6852 & 286,77 \\
\hline 5 & $\begin{array}{l}\text { Нараховано на зарплату єдиний соціальний } \\
\text { внесок 22\% }\end{array}$ & 92 & 651 & 6308,92 \\
\hline 6 & $\begin{array}{l}\text { Перераховано суму зарплати, що підлягає } \\
\text { зарахуванню на карткові рахунки працівнику на } \\
\text { транзитний рахунок }\end{array}$ & 313 & 311 & 22798,13 \\
\hline 7 & $\begin{array}{l}\text { Зараховано зарплату на картковий рахунок } \\
\text { працівника }\end{array}$ & 661 & 313 & 22798,13 \\
\hline 8 & $\begin{array}{l}\text { Виплачена зарплата через поточний банківський } \\
\text { рахунок }\end{array}$ & 661 & 311 & 22798,13 \\
\hline
\end{tabular}

Висновки. Отже, на підставі проведеного дослідження можна стверджувати, що оплата праці в Україні регулюється багатьма законодавчими і нормативно-правовими актами, серед яких є основною Конституція України, на основі якої базується все трудове законодавство; поняття «оплата праці», як соціально-економічна категорія служить основним засобом задоволення особистих потреб працівників; процес праці комунального некомерційного підприємства має певні особливості, так результатом виконаної роботи $\epsilon$ послуги діяльності, сама праця носить переважно розумовий характер, а у складі сукупних витрат на оплату праці персоналу КНП охорони здоров'я припадає від 65\% до 80\% усіх витрат; приведення обліку в Україні у відповідність до вимог міжнародних стандартів бухгалтерського обліку вимагає удосконалення обліково-аналітичного забезпечення та організації первинного обліку з оплати праці, що зумовлює актуальність розгляду даного питання.

\section{Лimepamypa:}

1. Конституиія України. URL: https://zakon.rada.gov.ua/laws/show/254\%D0\%BA/96\% D\%B2\%D1\%80\#Техt (дата звернення: 01.01.2022). 
2. Кодекс законів про працю України від 10.12.1971 № 322-VIII. URL: http://zakon.rada.gov.ua/laws/show/322-08 (дата звернення: 01.01.2022).

3. Податковий кодекс Украӥни від 02.12.2010 № 2755-VI. URL: http://zakon0.rada.gov.ua/laws/show/2755-17 (дата звернення: 01.01.2022).
4. Господарський
кодекс
України
вid
16.01.2003
№ 436-IV.
URL:

https://zakon.rada.gov.ua/laws/show/436-15\#Text (дата звернення: 01.01.2022).

5. Про оплату прачі : Закон Украӥни від 24.03.1995 № 108/95. Дата оновлення: 15.07.2021. URL: https://zakon.rada.gov.ua/laws/show/108/95-\%D0\%B2\%D1\%80 (дата звернення: 01.01.2022).

6. Національне положення (стандарт) бухгалтерського обліку 26 «Виплати працівникам». Наказ Міністерства фінансів Украӥни від 28.10.2000 № 601. URL: https://zakon.rada.gov.ua/laws/show/z1025-03\#Text (дата звернення: 01.01.2022).

7. Про впорядкування умов оплати праці праџівників закладів охорони здоров'я та установ соиіального захисту населення: наказ Міністерства праџі та соиіальної політики України, Міністерства охорони здоров'я Украӥни від 05.10.2005 № 308/519. URL: https://zakon.rada.gov.ua/laws/show/z1209-05\#Text (дата звернення: 01.01.2022).

8. План рахунків бухгалтерського обліку активів, капіталу, зобов'язань і господарських операиій підприємств і організаиій: наказ Міністерства фінансів Украӥни від 30.11.1999 № 291 . URL: http://zakon.rada.gov.ua/laws/show/z0892-99 (дата звернення: 01.01.2022).

\section{References:}

1. Konstytutsiya Ukrainy [Constitution of Ukraine]. zakon.rada.gov.ua. Retrieved from https://zakon.rada.gov. ua/laws/show/254\%D0\%BA/96-\%D0\%B2\%D1\%80\#Text [in Ukrainian].

2. Kodeks zakoniv pro pratsiu Ukrayiny: vid 10 december 1971 roku, № 322-VIII [Labor Code of Ukraine from Decemberb 12, 1971, № 322-VIII]. (n.d.). zakon.rada.gov.ua. Retrieved from http://zakon.rada.gov.ua/laws/show/322-08 [in Ukrainian].

3. Podatkovyi kodeks Ukrainy : vid 02 december 2010 roku, № 2755-VI [Tax Code of Ukraine from Decemberb 02, 2010, № 2755-VI]. (n.d.). zakon.rada.gov.ua. Retrieved from http://zakon0.rada.gov.ua/laws/show/2755-17 [in Ukrainian].

4. Hospodarskyi kodeks Ukrainy : vid 16 january 2003 roku, № 436-IV [Commercial Code Ukraine from January 16, 2003, № 436-IV). (n.d.). zakon.rada.gov.ua Retrieved from https://zakon.rada.gov.ua/laws/show/436-15\#Text [in Ukrainian].

5. Zakon Ukrainy "Pro oplatu pratsi” : vid 24 march 1995 roku, № 108/95 [Law of Ukraine “On Remuneration of Labor" from March 24,1995, № 108/95]. (n.d.). zakon.rada.gov.ua Retrieved from https://zakon.rada.gov.ua/laws/show/108/95-\%D0\%B2\%D1\%80 [in Ukrainian].

6. Ministry of Finance of Ukraine. National polozhennia (standart) bukhhalterskoho obliku 26 "Vyplaty pratsivnykam" : vid 28 zhovtnya 2000 roku, № 601 [National Regulation (Standard) of Accounting 26 "Employee Benefits" from Zhovtnya 28, 2000, № 601]. (n.d.). zakon.rada.gov.ua Retrieved from https://zakon.rada.gov.ua/laws/show/z1025-03\#Text [in Ukrainian].

7. Pro vporyadkuvannya umov oplaty pratsi pratsivnykiv zakladiv okhorony zdorovya ta ustanov sotsialnoho zakhystu naselennya: nakaz Ministerstva pratsi ta sotsialnoyi polityky Ukrayiny, Ministerstva okhorony zdorovya Ukrayiny : vid 05 zhovtnya 2005 roku, № 308/519 [On streamlining the conditions of remuneration of employees of health care institutions and social protection institutions: order of the Ministry of Labor and Social Policy of Ukraine, the Ministry of Health of Ukraine from Zhovtnya 05, 2005, № 308/519]. (n.d.). zakon.rada.gov.ua

Retrieved from https://zakon.rada.gov.ua/laws/show/z1209-05\#Text [in Ukrainian].

8. Ministry of Finance of Ukraine. Plan rakhunkiv bukhhalterskoho obliku aktyviv, kapitalu, zobov'iazan i hospodarskykh operatsii pidpryiemstv i orhanizatsii : vid 30 november 1999 roku, № 291 [Plan of accounting of assets, capital, liabilities and business operations of enterprises and organizations from November 30, 1999, № 291]. (n.d.). zakon.rada.gov.ua Retrieved from http://zakon.rada.gov.ua/laws/show/z0892-99 [in Ukrainian]. 